\title{
Conditional serendipity and Pablo Picasso
}

\author{
Tam-Tri Le \\ Centre for Interdisciplinary Social Research \\ Phenikaa University, Hanoi, Vietnam \\ 2022 January 16 \\ OSF Preprints
}

Serendipity has a vital role in major innovations [1,2]. It is an information process that can be examined through the Mindsponge mechanism $[3,4]$ and the $3 D$ framework of creativity [5].

The (seemingly subtle) conditionality of serendipity can be observed through some brilliant moments within the life of Pablo Picasso (1881-1973) - a worldwide famous artist, often known by the public for his extraordinary paintings in cubist and surreal styles. This Spanish artist went through many phases in his life, from poverty to huge success, with various layers of emotions toward major global events (such as World War I and II) as well as issues in his personal life. Picasso's paintings from 1901 to 1904 (known as his Blue Period) were mainly in shades of blue, usually depicted a rather gloomy atmosphere. His style during this period was influenced by the suicide of one of his friends. Furthermore, there was also an urban legend about how Picasso might have gotten to this style when he ran out of paint except for the color blue and experimented with monochromatic paintings. During Picasso's African Period (1906-1909), his painting style was heavily influenced by African art, such as masks, sculptures, and ancient drawings. In 1907, upon viewing African art in a museum at the Palais du Trocadéro, Picasso had a moment of striking inspiration that later led to his famous painting Les Demoiselles $d^{\prime}$ 'Avignon, where the characters' faces were (partially) based on the Iberian sculptures and African totem art that he had collected or had been shown earlier. This period, and particularly Les Demoiselles d'Avignon, served as the foundation for Picasso to develop and pioneer the revolutionizing style known as Cubism - one of the most influential art movements in the $20^{\text {th }}$ Century [6].

Expressing his thoughts on the adventure of creating art, Picasso said, "Je ne cherche pas, je trouve" [I do not seek, I find]. While Picasso highly valued venturing into the uncertainty with confidence and comfort, we need to acknowledge two very crucial underlying conditions leading to this artist's outstanding achievements: his expertise in art and his mindset at each specific time before innovation. Firstly, it is clear that Picasso was very talented regarding painting. Even when only at the age of 14 , he 
painted Portrait of Aunt Pepa - which was praised by art critic Juan Eduardo Cirlot as "without a doubt one of the greatest in the whole history of Spanish painting". In essence, this is similar to the common advice of "getting ready for when the opportunity comes". In terms of information processing, a certain value can only be realized if the mind is currently capable of processing such value. This is the knowledge aspect of the conditional background. Secondly, Picasso had suitable mental directions in relation to the "missing pieces" that made up the miraculous serendipity moments throughout his career. While many artists have witnessed the beauty of African art and the horror of war, Picasso was the one who connected all the right dots to produce Les Demoiselles d'Avignon and Guernica [7]. In essence, Picasso asked the "right" questions, and thus he was open and prepared to receive the "missing pieces". In terms of information processing, a certain value is only perceived as useful if one is currently in need of such value. This is the navigational aspect of the conditional background.

Update: More detailed discussions in the full book "A New Theory of Serendipity: Nature, Emergence and Mechanism" [8] (see References).

\section{Acknowledgement}

I would like to thank my mentor Dr. Quan-Hoang Vuong and my friend Minh-Hoang Nguyen for the insights.

\section{References}

1. Vuong, Q.-H., et al. (2022). Covid-19 vaccines production and societal immunization under the serendipity-mindsponge-3D knowledge management theory and conceptual framework. Humanities and Social Sciences Communications, 9, forthcoming.

2. Napier, N., \& Vuong, Q. H. (2013). Serendipity as a Strategic Advantage? In T. Wilkinson (Ed.), Strategic Management in the 21st Century (pp. 175-199). Westport, CT: Praeger/ABC-Clio.

3. Vuong, Q.-H., Nguyen, M.-H., \& Le, T.-T. (2021). A mindsponge-based investigation into the psycho-religious mechanism behind suicide attacks. Warsaw: Sciendo.

4. Vuong, Q. H., \& Napier, N. K. (2015). Acculturation and global mindsponge: An emerging market perspective. International Journal of Intercultural Relations, 49, 354-367.

doi:10.1016/j.ijintrel.2015.06.003

5. Vuong, Q. H., \& Napier, N. K. (2014). Making creativity: the value of multiple filters in the innovation process. International Journal of Transitions and Innovation Systems, 3(4), 294-327. doi:10.1504/IJTIS.2014.068306

6. Dasgupta, S. (2019). The Complexity of Creativity: Les Demoiselles D'Avignon as a CognitiveHistorical Laboratory. Creativity Research Journal, 31(4), 377-394.

7. Clark, T. J. (2013). Picasso and Truth: From Cubism to Guernica (Vol. 56). Princeton: Princeton University Press. 
8. Quan-Hoang Vuong. (2022). A New Theory of Serendipity: Nature, Emergence and Mechanism. Berlin, Germany: De Gruyter. 